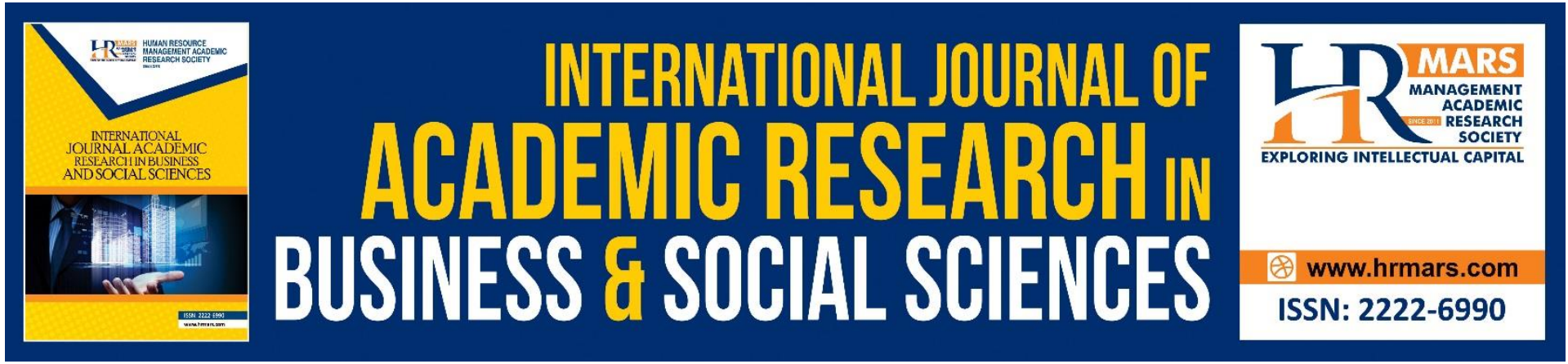

\title{
Symbolism in Pulpit Stairs of Terengganu New Mosque
}

\section{Noor Hafiza Ismail \& Hamdzun Haron}

To Link this Article: http://dx.doi.org/10.6007/IJARBSS/v11-i8/10614

DOI:10.6007/IJARBSS/v11-i8/10614

Received: 15 June 2021, Revised: 16 July 2021, Accepted: 03 August 2021

Published Online: 17 August 2021

In-Text Citation: (Ismail \& Haron, 2021)

To Cite this Article: Ismail, N. H., \& Haron, H. (2021). Symbolism in Pulpit Stairs of Terengganu New Mosque. International Journal of Academic Research in Business and Social Sciences, 11(8), 1312-1322.

Copyright: (C) 2021 The Author(s)

Published by Human Resource Management Academic Research Society (www.hrmars.com)

This article is published under the Creative Commons Attribution (CC BY 4.0) license. Anyone may reproduce, distribute, translate and create derivative works of this article (for both commercial and non-commercial purposes), subject to full attribution to the original publication and authors. The full terms of this license may be seen at: http://creativecommons.org/licences/by/4.0/legalcode

Vol. 11, No. 8, 2021, Pg. 1312 - 1322

http://hrmars.com/index.php/pages/detail/IJARBSS

JOURNAL HOMEPAGE

Full Terms \& Conditions of access and use can be found at http://hrmars.com/index.php/pages/detail/publication-ethics 


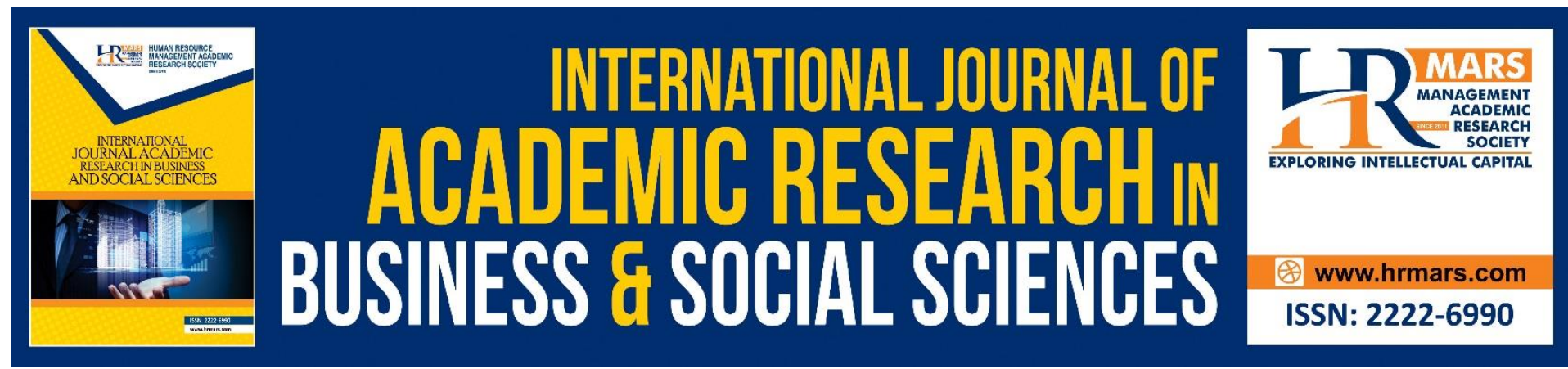

\title{
Symbolism in Pulpit Stairs of Terengganu New Mosque
}

\author{
Noor Hafiza Ismail ${ }^{1}, \&$ Hamdzun Haron ${ }^{2}$ \\ ${ }^{1}$ Faculty of Art \& Design, Universiti Teknologi MARA (UiTM), Malaysia, ${ }^{2}$ School of Liberal \\ Studies, Universiti Kebangsaan Malaysia (UKM), Malaysia. \\ Email: hh@ukm.edu.my
}

\begin{abstract}
A mosque is one of the many respected places of praying for the Muslims. It is one of rendezvous used by the Muslims for religious occasion like sermons, meetings and more. Nations around the world each has their own design to the pulpit of the mosques, basing on their own culture and ethnicity. Terengganu is one of the states in Malaysia that has possession a variety of unique and interesting carvings on a mosque's pulpits. The study aims to analyses the symbolism of pulpit stairs in a mosque in Terengganu. To clarify this point, a qualitative descriptive study with cultural approach is used. Interviews and observation methods were used in obtaining the data either written and visual image photo. The research found that the pulpit stairs are situated on the thigh part or leg according to human body structure. All stairs built in olden days and present time are situated on the front, right side of the pulpit. In addition, the number of stairs is usually in odd numbers, which is in line with Islamic values. However, there are also pulpit stairs at present which uses even numbers. All stairs built on the pulpit carries meaning which is related to human daily life that glorifies Allah SWT's greatness. The products of these wood carvings are evidence of the Malay's craftsmanship that should be preserved. It is hoped that this research would provide information to the public of the importance of preserving cultural heritage that gave identity to an ethnicity.
\end{abstract}

Keywords: Symbolism, Uniqueness, Stairs, Pulpit, Mosque.

\section{Introduction}

Uniqueness in Islamic art can be seen in the shapes and distinct characteristics which emphasize the usage of fauna, abstract, geometric and arabesque motif. Traditional element is also used in Islamic architecture tailored to Islamic element. It is decorated by creating nature motif which suits Al-Quran and As-Sunnah. In the selection of motif, Islamic designers are careful and meticulous in various motif layout aspects to avoid transgressions of Islamic demands. This goes hand in hand with Islamic art concept that displays its devotees' understanding of the power of Allah as the Creator (Yatim, 1989). In addition, the attention to detail in motif can be seen in the usage of fauna where the shape will not be used at all in accordance with Islamic art which prohibits the usage of animal elements. Usage of this motif will be stylized prior to usage to respect Islamic guidelines in art. Fauna inspired motif which 
are stylized can be depicted in 2 forms which is abstract and semi-abstract. In semi-abstract motif, it still maintains original fauna shape characteristics where the motif is still distinguishable. On the other hand, abstract form of stylized fauna motif eliminates the original shapes before being used as a sculpture.

In Terengganu, the uniqueness of the pulpit can be observed on the various engraving art adorning its structure. A lot of pulpits of old mosques are decorated with wooden engraving which can be seen on the surface of every space and corners of the pulpit. From the expertise of the sculptors, various interesting and unique design patterns are born. Usage of crests and symbols also reflect deep thought given in putting forth the local culture as the focus in a form of art. Uniqueness of engraving art by Islamic craftsmen represents the height of Islamic civilizations of the ummah itself where underneath the beauty of the engraving, therein lies meaning both stated and implied. Here it shows the subtlety in the production of Islamic art forms to present something of high value to the public. While the Islamic art is subtle, the meaning is nothing short of profound.

Good quality wood is used to create engraved pulpit from various types of embossed relief and direct piercing engraving. Careful consideration is taken in selection and woodworking as well as wood usage before going on to sculpting process. It is one of the aspects used by old and new craftsmen alike to ensure the sculpture carved out of the selected wood endures longer as well as easier to tear off according to desired motifs and patterns. The types of woods also depend on the shape or tools being produced such as whether to be used or as ornaments (Yusof et al, 2014). This is because sculptures of wood also influence the type of items and tool size whether big, medium or small.

It can be seen on the surface of the pulpit where there are fine and large engravings at certain corners as well as khat carvings. Usually, carvers use cengal wood as it is more durable to withstand termites. Nowadays, Merillia (kemuning), Merbau, and Nyatoh woods are more commonly used due to cengal's rarity and high price. By selecting good quality wood, not only it will be more beautiful to look at, but the wood work will consist of various colour tones such as dark brown to light brown. There is also wooden bark that has a natural almost black hue (Kosman et al., 2018).

\section{Literature Review}

Symbolism is used in Malay art as an expression of aesthetic values that signifies a shape or form. Symbolism not only gives function but also contains implied meaning to architecture. However, advancement in science and technology are becoming more and more parallel with the development of idea through human thought process (Ahmad, 2005; Dister, 1991; Haron \& Narimah, 2013). Symbolism can be seen in two forms namely constructive, or decorative. Constructive is defined as something that has the characteristics of building, developing and repairing in nature. Kamus Dewan Bahasa dan Pustaka on the other hand defined constructive as in which does not involve criticism. Decorative symbolism on the other hand is defined as ascribing meaning to the decoration form based on the level of meaning in visual symbols (Thakkar, 2004; Yusof et al., 2014).

Decorative in terms of meaning portrays not onto something that will be used as jewelry or ornament. Meanwhile, the next meaning defines decorative as something that attracts attention and can also be seen as a decoration. Decorative is similar with symbolism that gives different meaning according to the suitability towards the objects being used. While the meaning of symbolism from the Kamus Dewan is to use a sign which refers to the symbol 
intended to convey or pass on the information to others. The symbol or sign indirectly conveys information in various forms.

This is because symbols are not only seen in design but also in many aspects of life according to different understandings of time, place and things (Maryam et al., 2018). In addition to the arts, symbolism also includes important aspects of human life in sociology, psychology and philosophy. At the early stages, the component will form the 'symbol' while the later stages will look at the component referring to the 'meaning' of the produced symbol (Dillistone, 2002; Haron \& Narimah, 2014). Sometimes literal and figurative symbols in nature are inaccurate because they can convey different meanings and values according to respective understandings. Symbols are not only intellectual is nature but also stimulates the power of imagination of individuals in the interpretation of a particular visible symbol. The word symbol which is believed to be derived from the Greek word also symbolizes the object, function, process and idea of something.

Interpretation of meaningful symbol refers to symbolization of a form which explicit and implicit meaning can be understood. Meanwhile, symbolism derived from the word symbol is used to convey and state something deeper and more clearly. Symbolism can translate meaning beyond what is implied to be understood. This is because symbols can clarify the meaning of a visual. Symbolism functions as a medium or a tool to convey something implicit which enables comprehension of messages through deep level of understanding and appreciation (Yusof, 2008; Noh et al, 2015). Sound comprehension can foster relationship between groups, thus creating a community that communicates in two-way communication. This gives birth to openness and the equality among each other. Symbolism in this study can be seen on the structural design and pulpit engraving motif which are present in the state of Terengganu.

Each symbol produced is closely related with other Malay art. Symbolism is a symbolic representation of something. Symbolic means differently to those who is seeing where each understanding of human is different with each other. However, there are some universal symbols in which everyone here as well as other countries understands what it is trying to be conveyed in a visual way. For instance, the symbols of crescent moon and stars refer to Islam where it can be understood by people all over the world. However, the same cannot be said regarding the symbolism on pulpit engraving designs which can be seen clearly in mosques as the designs and motifs give different meaning according to the structure of pulpit.

\section{Finding and Discussion}

\section{Pulpit Stairs Design of Terengganu New Mosque}

Symbolism on the pulpit design is divided into three main structure namely head, body and leg. Each main structure consists of several smaller structures that don each part of pulpit. In this study, symbolism emphasis is given to the calves and thighs that refer to part of the stairs as shown in table $\mathrm{I}$.

The construction of the pulpit under study is found to have similarities to humans which can be described in three main categories consisting of head, body and legs as shown in the following table: 
Table 1. Similarities between pulpit design structure and human body structure

\begin{tabular}{|c|c|c|c|}
\hline No & $\begin{array}{l}\text { Main } \\
\text { limb }\end{array}$ & Smaller limb & Pulpit Structure \\
\hline 1 & \multirow{2}{*}{ Head } & Head & Roof \\
\hline 2 & & Neck & Upper engraving (roof) \\
\hline 3 & \multirow{3}{*}{ Body } & Shoulder & $\begin{array}{l}\text { Main engraving at upper } \\
\text { part. }\end{array}$ \\
\hline 4 & & Chest & $\begin{array}{l}\text { column and empty space } \\
\text { where khatib delivers } \\
\text { khutbah (to see khatib } \\
\text { clearly) }\end{array}$ \\
\hline 5 & & Stomach & Khatib's notes placeholder. \\
\hline 6 & \multirow{3}{*}{ Leg } & Buttock & Lower engraving \\
\hline 7 & & calf/thigh & Stairs \\
\hline 8 & & Foot & Base \\
\hline
\end{tabular}

The calf or thigh part of human is likened to the stairs of a mimbar. Just like a house with stairs, pulpits also consist of stairs that allows the khatib to go up and down from the pulpit safely. New pulpit stairs in each district in Terengganu consists of $3,5,6$, and seven steps. The stairs in the era of Rasulullah is located in front of the pulpit facing the makmum. The usage of 3 stair steps which began during the time of Rasulullah was increased to 6 steps by Marwan bin Hakam to make it higher due to the increase of worshippers who came to see Rasulullah delivering his khutbah. Increasing the height of steps does not go against the teaching of Islam as it is in accordance to the height and size or width of a particular mosque, where pulpits become a place where khatibs deliver khutbah during Friday prayers and Eid prayers to be seen by the congregation (Al-Qaradhawi, 2000).

It is observed that pulpit steps in Terengganu mostly consists of 3 to 7 steps. However, each pulpit has a different number of steps according to the district where some of the pulpits have 1 (Picture 1), 2 or 4 steps (Picture 2). The number of steps built is found to be based on the design of the pulpit according to the size, material, area and width of the mosque.
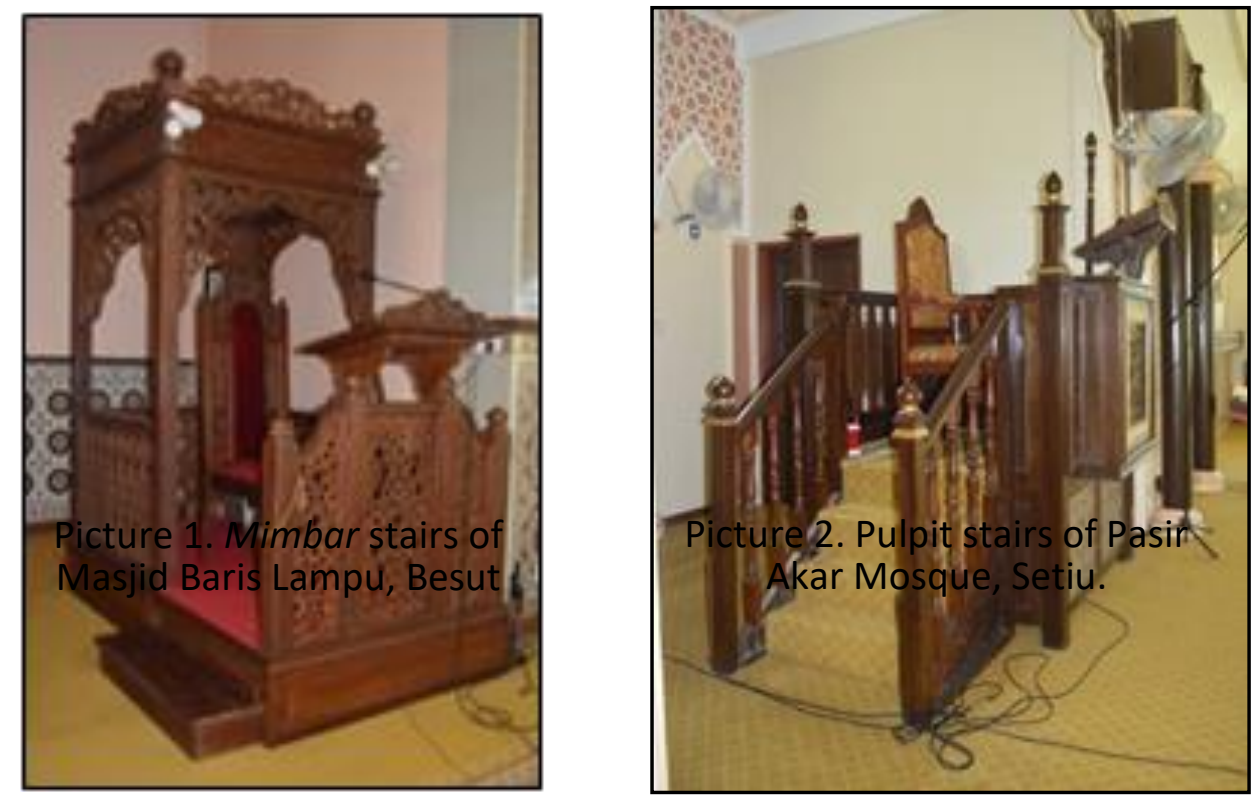
The steps on Rasulullah's pulpit consists of 3 steps but Rasulullah delivered his khutbahs facing the crowd on the second step and sat on the third. In the making of the pulpit, there is no compulsion to be excessive that forces the pulpit to be seen to be boastful (Anis, 2007). As a result, differences in the number of steps in Rasulullah's time and our time can be observed in terms of amount and arrangement of the steps where it is seen to be excessive nowadays. Following that, it makes matters difficult to foster the sunnah of Rasulullah in the construction of the stairs which is used to make it easy for the crowd or jemaah to see the face of the imam.

Pulpit stairs during Rasulullah's time is located at the front where when Rasulullah goes up the stairs, he will be facing away from the jemaah, but will face the jemaah when he delivers the khutbah. That way, all the jemaah present will be able to see Rasulullah's whole body clearly. However, most of the newer pulpits built around 2009-2014 being studied revealed that majority of the stairs are located at the right and not at the front such as at older mosques. The following is an example of the position of the old pulpit in Terengganu (Picture 3 ) showing that the stairs were in front of the pulpit as in the time of the Prophet.

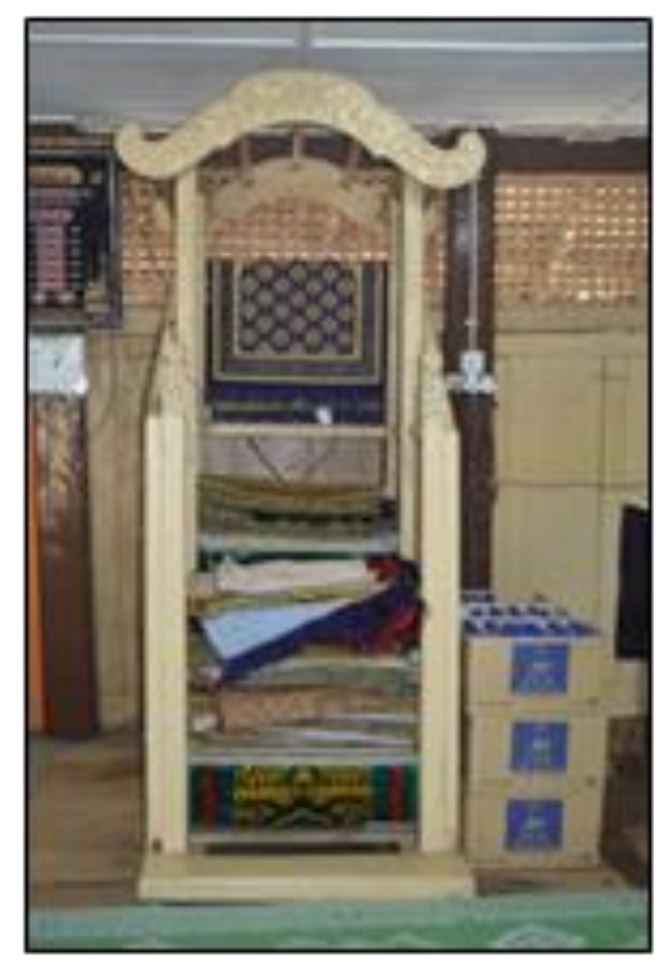

Picture 3. Pulpit of Old Mosque at Tuan Village, Kemaman

Pulpit stairs of old Mosque at Kampung Tuan, is believed to be the same with the age of the mosque which is over one hundred years which retains the Islamic architectural elements in accordance with the Prophet's sunnah. Aside from retaining the characteristics of sunnah in terms of placement design of the steps that faces the jemaah, it also retains the element of usage of only 3 steps. The stairs built are the same size and distance from the first and the next stairs. The width of the stairs is quite small compared to the size of the pulpit that is found in most of the old and new pulpit in Terengganu. The Mosque, built by Islamic scholar Syed Abdul Rahman Abdul Samad in 1830 from Pattani, Thailand, is under purview of Jabatan Warisan Negara through building conservation efforts conducted in 2006. The new position 
and the smaller size of steps might have suited the imam at that time. Despite the width of the stairs is smaller, the distance between one step to another seems rather far (Picture 4).

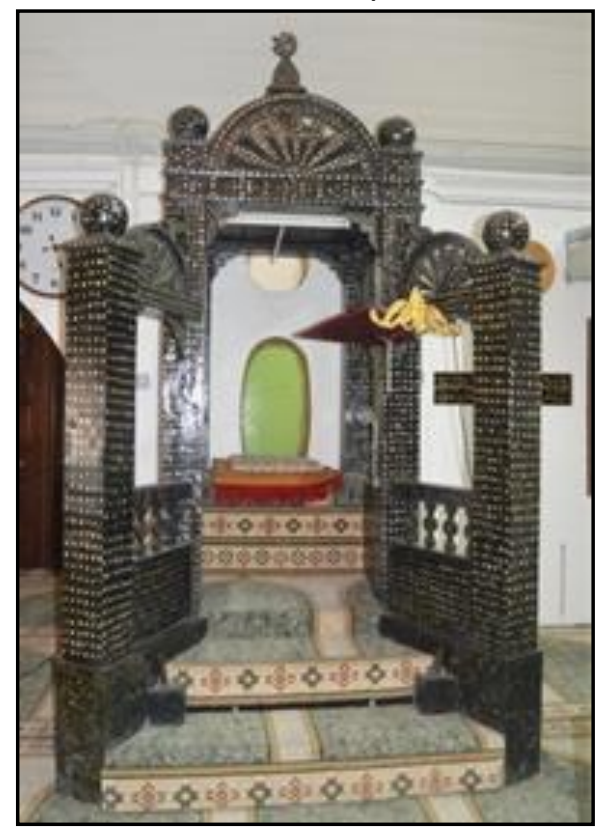

Picture 4. Pulpit of Al-Jamhuriah Old Mosque, Kuala Besut.

The size of the stairs in terms of width and height and the height of the pulpits being studied depends on the size of the pulpit of each state. The size of the steps also differs where the size of the width for the top stairs are usually wider as at that level, the imam's seat is placed. The seat mentioned is built with a chair to make it easy for the imam to deliver religious lectures or sermons. There are also some steps that are wider and higher up to the main plateau where the imam is seated. However, there are also a number of mosque pulpits that have wider first step than the second and third. Despite that, the steps for the stairs is longer and wider beginning from the first step, making it seem conical upwards and also decorated with designs.

The similar feature is also present in the stairs of old mosques in Terengganu. However, the stairs on the new Terengganu mosque is placed on the right side of the pulpit in respect to Islamic teaching to start doing something good from the right side. Pulpits which stairs is placed in the left is yet to be found as putting it on the left is frowned upon according to Islamic manners. The stairs from the right is also placed at the rear side of the pulpit as a sign of respect to the makmum coming to the mosque. By placing the stairs on the right naturally allows the khatib to ascend the stairs beginning with his right foot as it is made sunnah for the Islamic ummah that teaches to enter the mosque with the right foot. Most stair steps in the mosques consists of odd numbers just like the steps found in homes.

Each staircase built shall be fashioned with carving on the sides as a wall to the stairs and be built together with a handle to allow the khatib to hold when ascending the pulpit. The wall is built as a border on the right and left sides of the stairs from the first to the last stairs. The first step is built from the last base of the pulpit structure and continues to the pulpit or to two parts before the pulpit. This is because there are stairs that comprise of two parts of stairs depending on the design and size of a pulpit. The two-layer parts of stairs is built with three steps and the continued with another three steps. The construction of two-layer steps shows the stairs built do not end at the end of the pulpit. The pulpit staircase has a part at the top 
where the khatib delivers his khutbah. The size of the stairs also depends on the pulpit which is built according to the interior area of the mosque itself so that the pulpit size is proportional to the size of the mosque.

Next, the makmum can see the khatib clearly when the sermon is read. Each stair built are different in width. In terms of length of the steps, they are similar in size at each level of the steps but differs in width. Most of the first steps are wider if it is compared to the second and subsequent steps.

\section{Symbolic Meaning behind Pulpit Staircase of Mesjid Baru Terengganu}

The stairs can be divided into two parts namely ibu tangga (main stairs) and anak tangga (steps). Stairs refer to the religious philosophy where the main stairs act as a clamp for the steps (Mohamed, 1978). The steps are referred to as a symbol of Allah while the main stairs at the left and right symbolizes Prophet Muhammad as the messenger towards mankind.

Meanwhile, the steps represent the realm prior birth in mothers' womb. It is likened to Allah as the Creator of the universe where humans dwell on it. Human beings were created by Allah as caliphs being tasked to spread the teachings of Islam that enjoins humans to use the blessings of intellect and critical thinking to separate between righteousness and misguidance. The messenger to mankind is Rasulullah SAW who is the last prophet. The pulpit steps are built in odd numbers just like other houses and buildings. The number of steps in Mosque Terengganu consists of three, five, six, and seven. However, there are also a few pulpits that uses even numbers which is not according to Terengganu Islamic architecture philosophy.

It is likely that the makers of the pulpit did not study the art behind the construction of pulpits thoroughly. However, there are some pulpit makers that refer to appropriate authorities in designing the pulpits in which they would merely construct the pulpit from the design given to them. Therefore, all Islamic architecture needs to be given thorough attention to details because the Islamic architecture that is being produced is not the same as other architecture. The wonders of Islamic arts can be seen on every structure of the pulpit in which the steps will use odd numbers. The odd numbers can also see in Asmaul Husna that uses the 99 beautiful names of Allah (Yahya, 1995). The use of 3 steps in the stairs also refer to the Wahyu (revelation) which comes from Al-Quran and As-Sunnah.

Wahyu is kalamullah being recited to the Prophets and Messengers by the angel Jibrail. Wahyu which is symbolized to the stairs begin with the first steps that signifies the starting point for the khatib to ascend the stairs of the pulpit to deliver the khutbah. The information prepared must be conveyed to the makmum where it is compulsory upon them to listen to as a requirement for the Friday prayers. If there are no khutbah being read to the makmum prior to Friday prayers, then the prayers automatically become void and needs to be replaced with zuhur prayer. Wahyu becomes the base of iman of an individual as a symbol of submission towards the wahyu revealer which is Allah (Dister, 1991). Wahyu is divided into two meanings; a) iha in terms of the delivery while b) al-muha bihi which means the object of the wahyu itself. Iha is conveying something discreetly and quickly via writing and signals pertaining to the wahyu through the language itself that communicates the secret information through inspiration, gesture and writing (Abu Zaid, 2002).

Wahyu from inspiration is obtained from the heart or from dreams according to opinions of At-Tabari, Al-Razi dan Al-Zamakhsyari (Ali, 2004). Meanwhile Al-Raghib Al-Asfahani defines the meaning of wahyu as a fast-paced signal of words through symbols. According to 
terminology, wahyu also means Allah's message to the prophets and messengers in relation to syariah and hidden matters (Basyarahil, 2005). On the other hand, Al-Baydawi states wahyu is telling of something secretly in a short period of time. Testaments of prophet hood can be seen from the wahyu revealed to the prophets as divine covenant with Allah as the trustee. Revelation of wahyu to the prophets happens in three forms which are wahyu, revealed directly behind the scenes and through a medium which is via angel. Wahyu is specific as well as valuable as the information is from Allah S.W.T meant to those meant to receive it which are the messengers. Wahyu encompasses all aspects as guidance of Allah to human using AlQuran which acts as two-way communication as a gift and informer via Arabic language (Abu Zaid, 2002). Humans as servants of Allah is obligated to carry out Allah's commandments.

Al-Quran or kalamullah was sent to Prophet Muhammad S.A.W in masraf form and then spread to all mankind which becomes an act of worship in their daily life to read, memorize, and know in Arabic the meaning from Allah through the process of tawatur (Said et al., 2014). Al-Quran is a beacon of guidance to all human as the main source of law and solutions to all problems and questions. It is a guidance for all human to the righteous path and separates the righteous and misguidance. Al-Quran is defined as 'utterances or words from Allah in Arabic language that is mu'jiz or miraculous sent upon Rasulullah. Al-Qur'an which is revealed through the mediation of Jibrail is delivered through the process of tawatur beginning with surah Al-Fatihah and ends with surah An-Nas.

This is what differentiates between Al-Quran and other books of revelation brought down to the prophets before Rasulullah which are Taurat to Prophet Musa, Zabur to Prophet Daud, and Injil to Prophet Isa. In addition, Quran is also different from other books of revelation where it separates between the words of Allah and words of Rasulullah S.A.W. Words in AlQuran is the words of Allah while the hadeeth is the words of Prophet Muhammad S.A.W. AlQuran is a miracle which greatness is unmatchable. It is perfect in all aspects of life and social (Fadzil, 2007). Therefore, it is not an understatement that the meaning of Al-Quran itself means 'the perfect recitation' as there is no written things that exists since humans can write that can match the magnitude of Al-Quran. Al Quran is perfect in the arrangement of the sentences, timing of the sentences revealed, and the purpose being revealed to Rasulullah S.A.W. No religious scripture in any teachings contains implied or explicit meaning that leaves an impact to the reader as profound as Al-Quran (Shihab, 2007).

As-Sunnah is the second reference after Al-Quran to clarify sentences that require deeper interpretation. As-Sunnah in terms of language refers to the path travelled whether commendable or despised. On the other hand, in terms of syarak, Sunnah means all actions done by Rasulullah as an explanation to the meaning intended by Al-Quran in terms of words and actions (Ash Shiddieqy, 1986). In addition, all concurrence and explanation from appearance of Rasulullah that is good and commendable and all manners of worship is also included as As-Sunnah such as the way Rasulullah walks, eats and sits (Muhammad, 2005). As-Sunnah according to Ibnu Rajab Al-Hanbali is the travelled path by holding steadfastly with conviction to what the prophet and the rightly guided caliphs had done in words and action (Jawas, 2006).

As-Sunnah functions as musyarri as what has been stated in Al-Quran which is the first nas. According to Imam As-Syafi'i, Al-Quran is interpreted based on As-Sunnah which is the hadeeth which explains all laws and code of conduct (Farran, 2007). Besides functioning as interpreter to Al-Quran, Hadeeth also elaborates the sentences and explains comprehensively sentences which are general giving answers to all forms of decisions and evaluations to specific matters clearly in the Al-Quran. Further explanation given by Al-Quran encompasses 
all questions comprehensively which could not be accomplished by using mere logic and experiences. Therefore, sentences from Al-Quran requires interpretation from Prophet Muhammad S.A.W which functions to 4 forms such as act of solat, zakat, and hajj. Secondly, laws which scope are not yet clearly defined, thirdly regarding the specification of generic laws, while lastly explaining complex laws as the nature of Al-Quran itself is general and allencompassing.

\section{Conclusion}

The uniqueness of using the number of stairs on the pulpit is symbolic of the beauty of Islamic art. Each number of stairs uses odd numbers according to the size of the pulpit whether large, small, low or high. However, most pulpits in Terengganu use 3 or 5 steps. Each pulpit that considers the position of the stairs is definitely on the right corner of the pulpit. On the other hand, traditional or old pulpits have stairs located at the front part, facing the makmum. Each number carries its own meaning. It refers to the daily life of humans as the servants of Allah striving for happiness in the present and hereafter.

\section{Corresponding Author}

Dr. Hamdzun Haron

School of Liberal Studies (CITRA UKM), Universiti Kebangsaan Malaysia, 43600 Bangi, Selangor

Email: hh@ukm.edu.my

\section{References}

Jawas, Y. A. D. (2006). Bingkisan Istimewa Menuju Keluarga Sakinah, Pustaka At-Taqwa, Bogor.

Abu Zaid, N. H. (2002). Tekstualitas Al-Quran: Kritik terhadap Ulumul Quran, Lukis Pelangi Aksara. Yogyakarta.

Ahmad, A. A. (2005). Senibina Mosque-Antara Fungsi dengan Simbolisme, Available: https://www, utusan.com.my, (2005 August 25).

Ali Yasin, M. S., Haron, H., Ramli, Z., Masrek, M. N., \& Tular, S. (2018), The Ceramic Tableware Design Elements of Local Studio Ceramic Designers, International Journal of Mechanical Engineering and Technology (IJMET), vol. 9(5), pp. 1041-1048.

Al-Qaradhawi, Y. (2000). Tuntutan Membangun Mosque, Gema Insani Press, Jakarta.

Ash Shiddieqy, T. M. H. (1986). Pedoman Haji, P. T. Bulan Bintang, Johore Bahru.

Muhammad, B. S. O. (2005). Ahlus-Sunnah Wal Jama'ah: Keimanan, Sifat dan Kualitasnya, Gema insani press, Jakarta.

Basyarahil, U. (2005). Melahirkan Pemimpin Masa Depan, Gema Insani Press, Jakarta.

Dillistone, F. W. (2002). The Power of Symbol, Penerbit Kanisius, Yogyakarta.

Dister, N. S. (1991). Pengantar Teologi, Penerbit \& Percetakan Kanisius, Yogyakarta.

Fadzil, A. (2007). Anatomi Al-Quran: Mengenal Ilmu, Sejarah \& Kandungan Al-Quran, PTS Publication \& Distributor Sdn. Bhd, Selangor.

Farran, A. M. (2006). Tafsir al-Imam asy-Syaf i'i. Dar At-Tadmuriyyah, Riyadh.

Haron, H. \& Mutalib, N. A. (2013). Technology and Production Process of Malay Traditional Heritage Pottery in Malaysia, Jurnal Teknologi, 64:1, pp. 81-88.

Haron, H., Yusof, N. A., \& Mutalib, N. A. (2014). Factors Influence on Personal Practical Artwork, Mediterranean Journal of Social Sciences, vol. 5(27), pp. 1574-1586. 
Kosman, K. A., Haron, H., Tazilan, M. A. S., \& Yusof, N. A. (2018). "The Typology of Mortises in the Traditional Malay House in Malaysia", International Journal of Civil Engineering and Technology (IJCEIT), vol. 9(3), pp. 977-985.

Mohamed, A. (1978). Bentuk-Bentuk Bangunan Mosque: Kunci Memahami Kebudayaan Melayu, Kementerian Kebudayaan, Belia dan Sukan Malaysia, Kuala Lumpur.

Yatim, M. O. (1989). Warisan Kesenian Dalam Tamadun Islam, Dewan Bahasa dan Pustaka. Kuala Lumpur.

Noh, L. M. M., Haron, H., Samian, A. L. \& Hasan, (2015). A., Formalistic as an Analysis Method in Signifying the Malay Cultural Symbol in Malaysian Modern Art of Paintings, Mediterranean Journal of Social Sciences vol. 6(452), pp. 30-38.

Said, A., Abdul Wahab, N. A., Aris, H. R., Nawawi, H., Baharom, N. A., Mohd. Khalid, K., P. Rameli, M. F., Md Isa, M. F., Noormala, A. S., \& Ishak, N. (2014). Tunggak Kemuliaan Islam, Pusat Pemikiran dan Kefahaman Islam (CITU), Shah Alam.

Shihab, M. Q. (2007). Lentera Hati: Kisah \& Hikmah Kehidupan, Bandung: Khazanah Ilmu-ilmu Islam dalam seni Seni Bina Melayu Kelantan, Dewan Bahasa \& Pustaka, Kuala Lumpur.

Thahir, A. (2007). Petunjuk Nabi dalam Khutbah Jumaat. Jakarta: Pustaka Imam Asy-Syafi'I.

Thakkar, J. (2004). The Art of wood Carving in Traditional Houses of Gujarat: a Focus on Ornamentation, Research Cell School of Interior Design, C.E.P.T, Kasturbhai Lalbhai Campus, Gujarat India.

Ali, W. Z. K. (2004). Siapa itu Nabi-Nabi, PTS Publications, Bentong.

Yahya, M. A. (1995). Simbolisme dalam seni bina rumah Melayu Kelantan, Dewan Bahasa \& Pustaka, Kuala Lumpur.

Yusof, A. A. (2008). Mengurus Perubahan dalam Organisasi, Arah Pendidikan Sdn. Bhd, Selangor.

Yusof, N. A., Haron, H., \& Mutalib, N. A. (2014). Malacca Mosque: The Aesthetics of Old Mosques in Malaysia, Mediterranean Journal of Social Sciences, vol. 5(27), pp.1324-1437. 